\title{
Fodor, Ferenc. 2016. Fodor Ferenc önéletirásai ('The Autobiographical Writings of Ferenc Fodor'). Ed. Róbert Győri and Steven Jobbitt. Budapest: ELTE Eötvös József Collegium. 350 pp. Illus.
}

\author{
Reviewed by Andrew Behrendt ${ }^{*}$, University of Pittsburgh
}

It is rare enough to encounter as dedicated a chronicler of one's own life as geographer Ferenc Fodor (1887-1962); it is even more rare to find one who chronicles one's life in four different ways. Fodor Ferenc önéletirásai ['The Autobiographical Writings of Ferenc Fodor'] presents the autobiographical manuscripts of the prolific and influential interwar geographer in a single volume, bringing to light documents that until now only a very few specialists have had the benefit of reading. Transcribed, edited, and presented with an Introduction in both Hungarian and English by two experts in Fodor and his field, Róbert Györi and Steven Jobbitt, these texts impart an intimate perspective on over six decades of East-Central European history. Seen as a whole, they also prove to be a useful accompaniment to Fodor's extensive professional body of work, which spanned not only the last years of the Habsburg Monarchy and the early years of the People's Republic of Hungary, but multiple academic disciplines as well. Whereas Fodor's diaries and memoirs reveal the effects of national and world events on an individual life, his narratives of his personal life likewise showcase the entanglement of biography, scholarship and nationalism in an unexpectedly engaging fashion.

The four documents included in this volume are preceded by a substantial Introduction presented first in Hungarian and then in English translation. For readers of Hungarian, the Introduction gives a handy guide to the writings that follow, while also drawing them together into a single, cohesive autobiography. For Anglophones without any knowledge of Hungarian, the English Introduction efficiently summarizes the entire book and thus serves as a solid standalone entrée to Fodor and his oeuvre, all the more so since it also offers a review of recent scholarship on both.

The first of the documents is "Emlékezetül" [translated by the editors as "Recollections"], and in it Fodor surveys his life up to the middle of 1931. Although rather brief, this mini-memoir anchors some of the central threads that run through the entire volume. In this part we learn about Fodor's recurring concern to prove that Hungarian blood runs through his veins and that he is firmly planted in Hungarian soil; moreover, having been born in the village

*aeb72@pitt.edu

(cc) $\mathrm{EY}$

ULIS D-Senle
New articles in this journal are licensed under a Creative Commons Attribution 4.0 International License.

This journal is published by the University Library System of the University of Pittsburgh as part of its D-Scribe Digital Publishing Program and is cosponsored by the University of Pittsburgh Press 
Behrendt, Andrew. "Fodor, Ferenc. 2016. Fodor Ferenc önéletirásai ('The Autobiographical Writings of Ferenc Fodor'). Ed. Róbert Győri and Steven Jobbitt. Budapest: ELTE Eötvös József Collegium. 350 pp. Illus.” Hungarian Cultural Studies. e-Journal of the American Hungarian Educators Association, Volume 10 (2017) DOI:

of Tenke (Romanian: Tinca) in the Eastern Bihar County, he sees himself a faithful native son of Hungarian Transylvania. In his mature life he will be just as proud of realizing his dream of owning a home in Budapest, on a piece of Hungarian land earned through intellectual toil that would see him through hard times and to his early nineties.

Throughout this document we also witness Fodor's contempt for Romanians, to whom he refers to throughout by using, almost exclusively, the derogatory term oláh ['Vlach/ian']. In fact, this appellation really blossoms in his text after he is assigned as a teacher, in 1911, in the Karánsebes (Caransebeş) gimnázium, a state high school in the Bánát County. Accordingly, he shows disdain of the area, which he sees as a "Vlach nest" (86), whose backwardness threatens to irrevocably corrupt the "once purely Magyar landscape" (88). Thus we see that for Fodor, the study of Hungarian geography is inseparable from communing with the Hungarian homeland and expressing oneself on its behalf. No wonder, therefore, that he also becomes passionately involved in the Hungarian Boy Scouts (94).

Next comes a document entitled "Curriculum Vitae," which Fodor assembled in 1940 as part of his (unsuccessful) application for a position as Chair of Human Geography at Péter Pazmány University in Budapest (today's ELTE). While many readers are familiar with the socalled genre of the formal academic $\mathrm{CV}$, this one is written in a distinctly narrative form and contains some unexpected (for the genre) genealogical details. The opening section spells out the birthdates, birthplaces, and religious affiliations of both the author and his wife Vira, as well as those of their parents and grandparents, and concludes in an affirmation that neither of them has any Jewish blood (105-6). As Györi and Jobbitt suggest in their Introduction (62), it seems reasonable to surmise that in emphasizing his and his wife's non-Jewish roots, Fodor was responding to the dictates of the Second Jewish Law of 1939, which was designed to further expel Jews from universities and other public spheres.

The third documents in the book is called "Életem eseményei" ['My Life's Events'] and it consists of a series of diary-style entries in which Fodor enumerates and occasionally comments on his life experiences in the period between 1887 and 1959. Surprisingly, perhaps, this document is not a tedious account. Rather, it reads like a rapid-fire chronicle that, regarding periods of world-historical turmoil, could even be read with the pace of a page-turner. Indeed, the sections on World War One, the breakup of the Habsburg Monarchy, and the collapse of the Nazi Axis in the Eastern Front during World War Two are especially compelling, as they combine Fodor's matter-of-fact style with his intimate perspective. These sections present us with a laconic yet engrossing narrative about overwhelming events bearing down upon a single family, like a boat faced with the building gale. The text waxes and wanes in verbosity, throwing extra light on certain parts of Fodor's life and character as opposed to very minimal attention to other parts, thus hinting, perhaps, at the psychological consequences of the adversities he suffered. For example, as an inveterate academician he cites the precise contents of his high school exams; but this prolix Fodor is nowhere to be found in the last pages, which consist mainly of terse observations on the weather, as by then he was living in virtual professional exile and penury under the Rákosi regime of the 1950s.

The final and most substantial document is "Élettörténet" ['Life History'], a narrative memoir that Fodor composed in segments between 1941 and 1950. The period covered here, however, although occupying around 120 pages, does not extend beyond 1923. Alongside "Emlékezetül" and "Életem eseményei," this account helps to assign the book with a distinctly 
Behrendt, Andrew. "Fodor, Ferenc. 2016. Fodor Ferenc önéletirásai ('The Autobiographical Writings of Ferenc Fodor'). Ed. Róbert Győri and Steven Jobbitt. Budapest: ELTE Eötvös József Collegium. 350 pp. Illus.” Hungarian Cultural Studies. e-Journal of the American Hungarian Educators Association, Volume 10 (2017) DOI:

10.5195/ahea.2017.303

"front-heavy" feel, meaning that the author seems to have substantially more to say about his distant past - especially his school years and early career - than about later periods in his life. It is, indeed, the younger Fodor that this volume enables us get to know best: the hard-working and ambitious scholar whose climb to the pinnacle of the Hungarian intelligentsia met with frustration; the suitor and then husband of a woman who apparently suffered from many health issues; the doting father, especially to his son Zoli who died at age 20; and a committed Boy Scout leader, whose diaries of travel abroad close out the volume.

"Élettörténet" gives us the deepest view onto the personal experiences and habits of mind of Ferenc Fodor that help explain the nationalist-irredentist ideology framing much of his work. His memoir begins not with his own life, but rather with the establishment of his racial bona fides: so far back does his "pure" Hungarian ancestry run, and so deeply rooted is it in the Hungarian soil, that he professes to feel his homeland in his blood and soul (246). Then comes his political awakening, as the electoral crisis of 1905-1906 and the culture wars surrounding it rouse him against liberalism (264), which he later blames for the introduction of a "fashionable" but harmful materialism into Hungarian society (285). From there, Fodor's nationalism and conservatism politics flow into what might be called a colonialist mentality regarding his time in the Banát County. He feels himself surrounded by benighted indigenes and seems to have assumed that, as an educated Hungarian and a Hungarian educator, he is the stalwart torchbearer of a superior people (291). This comes across most clearly in Fodor's accounts of Karánsebes, where he holds his first permanent teaching job, to which he diligently applied himself; but it is also a wretched, frustrating experience, and he writes of it as a person shipped off to some desolate outpost at the edge of civilization. He finds the conditions around him "primitive" (289, 293) and "scarcely touched by Hungarian culture" (289). In spite of the potential this "virgin terrain" of Karánsebes holds for an industrious civilizer (289), Fodor flees after the tables turn on Magyar hegemony in 1918-1919 (312-22), and his labors "on behalf of Hungarian culture" (322), performed at the expense of his career ambitions, turn out to have been in vain (327).

It should be noted that following the second and third documents are long interludes of photographs from Fodor's personal collection, amounting to a total of fifty images in all. Some of these illustrate a few of the main personages mentioned in the texts at various stages in their lives; others show scenes from where the Fodors resided or traveled, and a handful reflect the family's avid involvement in Scouting. Arranged chronologically, the photos are remarkably telling. By the point at which they conclude with a picture of Fodor's grave marker, we have read through the course of his life three times over: seen him be born, educated, and face hardship time and again in his late middle-age.

How the reader will profit from a book like this depends very much, of course, on what interest she or he has in Fodor specifically or in his era more generally. In addition to the topics highlighted above, one could also find here intriguing material, for instance, for understanding casual interwar antisemitism, or for exploring the material realities of education and intellectual labor in early twentieth-century East-Central Europe. For their part, Györi and Jobbitt propose that the documents provide "insight into the way a middle-class conservative-nationalist intellectual of admittedly humble origins dealt with not only the immediate concerns of his personal and professional life, but also with pressing issues like economic hardship, political change, social marginalization, Hungary's territorial dismemberment, and the trauma of war more generally" (60). The book amply delivers on these broad promises, and on that basis alone 
it is a recommended reading. It makes a valuable companion to the work of Györi and Jobbitt themselves, naturally, but also to literature on the key figures in and cultural products of Hungarian irredentism, such as Balázs Ablonczy's biography of Pál Teleki (2006), Miklós Zeidler's Ideas on Territorial Revision in Hungary (2007), and Holly Case's Between States the Transylvanian Question and the European Idea during World War II (2009). Anyone researching the development of human geography and Honismeret (regional/local history, or more accurately "knowledge of one's homeland") in Hungarian intellectual history will not want to pass by this opportunity to better understand one of the field's most important practitioners. 